\title{
Erozyon Sahalarında Yetişen Devekıran (Atraphaxis spinosa L.) Bitkisinin Taç l̇çi/Dışı ile Farkıı Derinliklerdeki Toprakların Bazı Toprak Özelliklerine Etkisi
}

\section{Bahattin KARAKUŞ' ${ }^{\mathbb{D}}$, Bilal KESKIN*2 (i)}

\author{
'Iğdır Tarım Kredi Kooperatifi, IĞDIR.
}

2lğdır Üniversitesi, Ziraat Fakültesi, Tarla Bitkileri Bölümü, IĞDIR.

Özet: Bu çalışma, lğdır ili Aralık ilçesi sınırlarında erozyon sahasında kendiliğinden yetişen Devekıran (Atraphaxis spinosa L.) çalısının taç içi/taç dışı ile farkı derinlikteki $(0-20,20-40$ ve 40-60 cm) toprakların bazı özelliklerinde meydana gelen değişiminin belirlenmesi amacıyla 2015 yılında yürütülmüştür. Araştırmada toprakların pH, EC, kireç, OM (organik madde), N (azot), P (fosfor), $\mathrm{Na}$ (sodyum), $\mathrm{Ca}$ (kalsiyum), $\mathrm{K}$ (potasyum) ve Mg (magnezyum) içerikleri belirlenmiştir. Devekıran (Atraphaxis spinosa L.) çalııının taç dışı kısmından alınan toprak örneklerinin pH değeri (8.05) taç içi kısmından alınan değerlere göre daha yüksek çıkmıştır. Oysa bitkinin taç içi kısmından alınan örneklerin kalsiyum (\%4.99), potasyum (\%0.52) ve magnezyum (\%0.63) taç dışı kısmından alınan değerlere göre daha yüksek çıkmışır. Toprağın fosfor, sodyum, potasyum ve magnezyum içerikleri toprak derinliklerine bağı olarak değişiklik göstermiş, diğer incelenen toprak özellikleri toprak derinliğine bağlı olarak herhangi bir değişikliğe uğramamıştır. Fosfor ve potasyum içeriği toprağın orta derinliğinde $(40-60 \mathrm{~cm})$, potasyum ve kalsiyum içeriklerinin ise daha yüzey topraklarda $(0-20 \mathrm{~cm})$ daha fazla biriktiği görülmüştür.

Anahtar Kelimeler: Atraphaxis spinosa L. besin içeriği, çalı, dönem

\section{Effects on Some Soil Properties of Soils in Different Deeps With Internal and External Canopy of Goat's Wheat (Atraphaxis spinosa L.) Growing on Erosion Fields}

Abstract: This study was conducted to determine the changes that occur in some features of soil at inside and outside of canopy and different soil depths $(0-20,20-40$ and 40-60 cm) of Goat's wheat (Atraphaxis spinosa L.) grows spontaneously at Aralik town of Igdir in 2015 year. In this research, pH EC, lime, OM (organic matter), N (nitrogen), $\mathrm{P}$ (phosphorus), Na (sodium), Ca (calcium), K (potassium) and Mg (magnesium) content of the soil were determined. $\mathrm{pH}(8.05)$ of soil samples taken from outside of canopy of Goat's wheat (Atraphaxis spinosa L.) is higher than the value from the inside of canopy. However, calcium (4.99\%), potassium (0.52\%) and magnesium (0.63\%) contents of soil samples taken from the inside of canopy of the plant is higher than the value from outside of canopy. Soil phosphorus, sodium, potassium and magnesium contents were varied depending on the depth of soil, other soil properties studied did not suffer any changes depending on the soil depth. Phosphorus and potassium contents of soil medium depths (40-60 cm), and also potassium and calcium content of surface soil $(0-20 \mathrm{~cm})$ accumulated more than other soil depths.

Keywords: Atraphaxis spinosa L. nutrient content, shrub, period

\section{GiRiş}

Ülkemizde doğal çayır meralarımız, geviş getiren hayvanların tabi besin kaynağı olup, uzun yıllardan beri devam eden erken ve aşırı otlatmalardan dolayı verim güçlerini kaybettikleri gibi bu alanların çoğu erozyona maruz kalmış ve çoraklaşmış durumdadır. Çalıların kullanımı konusunda Akdeniz ülkelerinde büyük mesafeler kaydedilmiştir. Birçok ülke çalı formu bitkilerle geniş alanlarda tesis oluşturarak hem yem kaynağı oluşturmuş, hem de erozyonu azaltmıştır. Türkiye de dahil bazı ülkeler ise bu gelişmelere kayıtsız kalmışlardır. Türkiye toprak erozyonunun şiddetli bir şekilde yaşandığı ülkelerden biridir. Araştırma sonuçlarına göre yaklaşık \%88.7'sinden fazla bir alanda değişik şiddet ve derecede toprak erozyonu görülmektedir (Koç ve ark., 1994).

Erozyon canlı organizmaların yeterli faaliyet gösteremediği ekstrem iklim ve toprak şartlarının yaşandığı alanlarda daha fazla önemlilik arz etmektedir. Bunun gibi kurak ve yarı kurak bölgelerde pek çok kültür bitkisi hayatiyetlerini devam ettiremeyip, yeterince üretim sağlayamadığı gibi, toprak ve su muhafazası açısından da etkin rol oynayamazlar. Oysa doğal ekolojik koşullarda yetişen pek çok çalı ve odunsu türler; sahip oldukları derin ve kuvvetli kök sistemleri sayesinde kuraklığa toleransları yüksek olup, pek çok kültür bitkisinin gelişemediği alanlarda rahatça yetişebilmektedirler. Ayrıca kalite kayıpları otsu türlere nazaran daha az veya yavaş olduğundan ruminantlar için enerji ve besin içeriği yüksek, vitamin ve mineral maddeler yönünden zengin yem materyali üretebilmektedirler (Temel ve Tan, 20I I; Ahmad ve ark., 2008; Ghazanfar ve ark., 20II; Tan ve Temel, 2012).
Doğu Anadolu bölgesinin karasal iklim şartlarındaki illerine göre, Iğdır ili sahip olduğu mikroklima iklim özelliğinden dolayı, yetiştirilebilecek tür çeşitliliği daha fazladır. Ancak bilinçsiz kullanım ve ekolojik yapıdan kaynaklanan etmenler, yetiştirilebilecek ürün çeşitliliğinin azalmasına, toprakların çoraklaşmasına ve erozyona açık alanlar haline dönüşmesine neden olmuştur. Sonuçta bu alanlar 36,476 ha alan tuzlulaşmadan, 13,542 ha'lık alan ise rüzgar erozyonundan dolayı üretim güçlerini yitirdiklerinden, ekonomik anlamda bitki yetiştiriciliği yapılamamaktadır (Temel ve Şimşek, 20I I; Özdoğan, 1976).

Genel olarak bitki örtüsünden yoksun toprakların rüzgar erozyonuna maruz kalma dereceleri ve erozyon sonucu oluşan toprak kayıpları fazladır. Bu nedenle rüzgar erozyonu sonucu toprağın verimli üst kısmı uzaklaştırıldığından, geride organik madde ve besin içeriği yönünden fakir bir toprak kalmaktadır. Bu amaçla rüzgar erozyon sahalarında yüzeydeki toprak hareketliliğinin hızını ve miktarını yavaşlatmak için rüzgar perdeleri ve rüzgar kıranlar yaygın olarak kullanılan yöntemlerdendir. Rüzgar perdelerinden kasıt canlı bitki materyallerinin kullanılmasıdır. Ancak bu gibi alanlarda bölgenin sahip olduğu ekstrem iklim ve toprak yapısından kaynaklanan sebeplerden dolayı yetiştirilebilecek bitki tür sayısı kısıtı ve

*Sorumlu Yazar: bilalkeskin66@yahoo.com

Bu çalışma ilk yazarın yüksek lisans tezi ürünü olup lğdır Üniversitesi Bilimsel Araştırma Projeleri Koordinasyon Birimi tarafindan desteklenmiştir.

Geliş Tarihi: 12 Nisan 2017

Kabul Tarihi: 16 Ağustos 2017 
bitki tesisi oluşumunda ise başarı oranı çok düşüktür. Buna karşılık bu alanlarda doğal olarak yetişen hakim çalı formasyon tiplerinden bir taneside Devekıran (Atraphaxis spinosa L.) çalısı olup, rüzgar erozyununu önlemede de önemli bir görev üstlenmiştir.

Çalı ve ağaç türlerinin alternatif yem kaynağı olarak kullanılmalarının yanında pek çok amaç için tercih edilmekte olup farklı kullanım alanları bulunmaktadır. Diğer taraftan çalı bitkilerinin sahip oldukları kuvvetli kök sistemleri ve toprak üstünde oluşturdukları kanopileri sayesinde toprağın organik madde yönünden zenginleştirmektedir (Tan ve Temel, 20I2). Bu çalışma, Iğdır ili Aralık ilçesi sınırlarında erozyon sahasında kendiliğinden yetişen ve rüzgar erozyonunun önlenmesinde rüzgar perdesi olarak rol oynayan Devekıran (Atraphaxis spinosa L.) çalısının taç içi/taç dışı ile farklı derinlikteki toprakların bazı özelliklerinde meydana gelen değişiminin belirlenmesi amacıyla yürütülmüştür.

\section{MATERYAL ve YÖNTEM}

Çalışma sahası, ülkemizin ikinci büyük rüzgar erozyon sahası olup, ortalama 825 m rakım kotunda, 30 km Doğu Batı, 4-5 km Kuzey Güney uzunluğunda ve toplam 13,542 hektarlık bir alana sahiptir (Temel ve Şimşek, 201 I; Özdoğan, 1976). Rüzgar erozyon alanının arazi kullanımı bakımından incelendiğinde 6,700 hektarlık alanın fundalık alan, 6,842 hektarlık alanın da ikinci sınıf mera alanı durumunda olduğu belirtilmiştir (Sevim, 1999). Mevcut mera alanının 5,524 hektarı taşlı alan konumundadır. İklim özelliği yönünden Doğu Anadolu Bölgesi'nden farklı bir yapı göstermektedir. Yazları sıcak ve kurak, kışları ise soğuktur.

Mevcut çalışma, Iğdır ekolojik koşullarında yetişen Devekıran (Atraphaxis spinosa L.) bitkisinin taç içi/taç dışı toprakların bazı özellikleri incelenmiştir. Devekıran bitkisinin yoğun olarak geliştiği alanlarda bitkinin taç içi ve taç dışı ile farklı derinlikte (0-20, 20-40 ve 40-60 cm) alınan toprakların $\mathrm{pH}$ (toprak reaksiyonu), $\mathrm{EC}$ (elektriksel iletkenlik), $\mathrm{CaCO}_{3}$ (kireç), OM (organik madde), N (azot), P (fosfor), $\mathrm{Na}$ (sodyum), $\mathrm{Ca}$ (kalsiyum), $\mathrm{K}$ (potasyum) ve $\mathrm{Mg}$ (magnezyum) miktarları belirlenmiştir. Araştırma ve veriler bölünmüş parseller deneme desenine göre üç tekerrürlü olarak kurulmuş ve istatistiksel analizleri yapılmıştır.

Belirlenen çalı öbeklerinin taç izdüşümü kısımlarından ve çalı öbekleri dışında kalan kısımlarından 0-20 cm, 20-40 cm ve 40-60 cm derinliklerden bir burgu aracılığıyla toprak örnekleri alınmıştır. Bu amaçla, her bir blok içerisinde belirlenen 5 farklı çalı öbeğinin taç iz düşümü ile kök boğazı bölgesi arasında kalan kısımdan ve blok aralarından belirlenen farklı toprak derinliklerinde toprak örnekleri alınmış ve torbalar içerisine konulmuştur. Sonra her bir çalı kümesinden alınan toprak örneği karma yapılarak tek bir örnek haline getirilmiş ve bir tekerrür oluşturulmuştur. Yine her bir blok arasında kalan kısımlardan da, alanı temsil edecek şekilde 5 farklı yerden toprak örnekleri alınmış ve alınan toprak örnekleri yine karma yapılarak tek bir örnek oluşturulmuştur. Bu işlemler diğer bloklar için de tekrarlanmıştır. Daha sonra örnekler havada kurutularak öğütülmüş ve 2 mm'lik elekten geçirilerek aşağıdaki toprak analizleri yapılmıştır.

Toprak reaksiyonu (pH): Alınan toprak örneklerinin $\mathrm{pH}^{\prime}$ । I:2.5 toprak su karışımında potansiyometrik olarak cam elektrotlu pH - metre ile bulunmuştur (Sağlam, 1994).

Elektriksel iletkenlik (EC dSm-I): Saturasyon macunlarından elde edilen ekstraksiyon süzüklerinde elektriki kondüktivite aleti ile bulunmuştur (Rhoades, 1982).

Kireç içeriği $\left(\mathbf{C a C O}_{3}\right)$ : Alınan örnek toprakların kireç içerikleri Scheibler Kalsimetresi ile volümetrik olarak belirlenmiştir (Nelson, 1982).

Organik madde içeriği (OM): Alınan örnek toprakların organik madde içerikleri Smith-Weldon yöntemiyle bulnmuştur (Nelson ve Sommers, 1982).

Toplam azot (N): Alınan örnek toprakların azot içeriği salisilik asit + tuz karışımı ile yaş yakmaya tabi tutulduktan sonra mikro kjheldahl yöntemiyle bulunmuştur (Bremner ve Mulvaney, 1982).

Elverişli fosfor $\left(\mathbf{P}_{\mathbf{2}} \mathbf{O}_{\mathbf{5}}\right)$ : Alınan örnek toprakların elverişli fosfor içerikleri asit florürde çözünebilir fosfor mavi renk yöntemiyle belirlenmiştir (Sağlam, 1994).

Değişebilir katyonlar: Alınan örnek toprak örneklerinin katyonları ( $\mathrm{Na}, \mathrm{Ca}, \mathrm{K}$ ve $\mathrm{Mg}$ ) miktarları sodyum asetatla ( I $\mathrm{N}$, $\mathrm{pH}=8.2$ ) sodyum adsorbsiyonu sağladıktan sonra amonyum asetatla ( I N, pH = 7.0) ekstrakstrakte edilen solüsyonlarda IPC-OES Inductively Couple Plasma Spectrophometer (Perkin-Elmer, Optima 2100 DV, ICP/OES, Shelton, CT 06484-4794, USA) ile okuması yapılarak belirlenmiştir (Rhoades, 1982).

\section{BULGULAR ve TARTIŞMA}

Mevcut çalışmada Devekıran çalısının geliştiği toprakların farklı derinlik (0-20, 20-40 ve 40-60 cm) ve taç içi/taç dışı alınan toprakların incelenen parametrelerine ait varyans analiz sonuçları Çizelge I'de verilmiştir. Çizelge I incelendiğinde, taç içi ve taç dışı kısımları arasında toprakların kalsiyum, potasyum ve magnezyum içerikleri $p<0.0$ I ihtimal seviyesinde çok önemli; toprağın $\mathrm{pH}$ 'sı ise $\mathrm{p}<0.05$ ihtimal seviyesinde önemli bulunmuştur. Taç içi ve dışında alınan toprakların EC, kireç, organik madde, azot, fosfor ve sodyum içeriklerinde ise önemli bir farklıık olmamıştır.

Derinlik açısından incelendiğinde kalsiyum ve potasyum içerikleri $p<0.0$ I ihtimal seviyesinde çok önemli, fosfor ve sodyum $\mathrm{p}<0.05$ ihtimal seviyesinde önemli, toprağın $\mathrm{pH}$, EC, kireç, organik madde, azot ve magnezyum içerikleri ise önemsiz bulunmuştur.

Taç içi ve dışı farklı derinliklerden alınan toprak örneklerinin $\mathrm{pH}$ ve EC değerleri ile kireç içeriği Çizelge 2'de, organik madde, azot, fosfor miktarları Çizelge 3'de, sodyum, kalsiyum ve potasyum içerikleri Çizelge 4'te, magnezyum miktarları ise Çizelge 5'de verilmiştir.

Devekıran çalısının taç dışı kısmından alınan toprak örneklerinin $\mathrm{pH}$ değeri (8.05) taç içi kısmından alınan değerlere göre

Çizelge I. Incelenen toprak özelliklerine ait varyans analiz tablosu

\begin{tabular}{|c|c|c|c|c|c|c|c|c|c|c|c|}
\hline \multirow{2}{*}{$\begin{array}{l}\text { Varyasyon } \\
\text { Kaynakları }\end{array}$} & \multicolumn{11}{|c|}{ F Değerleri ve Onemlilik } \\
\hline & SD & $\mathbf{p H}$ & EC & Kirec & OM & $\mathbf{N}$ & $\mathbf{P}$ & $\mathbf{N a}$ & $\mathbf{C a}$ & $\mathbf{K}$ & $\mathrm{Mg}$ \\
\hline Taç İçi/Dışı & I & $8.04 *$ & $2.750 ̈ \mathrm{~d}$ & I.79öd & 0.22 öd & 0.25 öd & I.10öd & 0.002öd & $32.47^{* * *}$ & $93.69 * *$ & $12.43^{* * *}$ \\
\hline Derinlik & 2 & I.I5öd & I.32öd & I.87öd & 2.19öd & 2.19öd & $4.22 *$ & $4.54^{*}$ & $16.15^{* *}$ & $44.51 * *$ & $2.950 ̈ \mathrm{~d}$ \\
\hline Taç İçi/Dıșı x Der.İnt. & 2 & $17.08 * *$ & 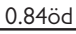 & I.82öd & 0.08 öd & $0.08 \mathrm{öd}$ & $2.95 \mathrm{öd}$ & $2.61 \mathrm{öd}$ & $12.20^{* *}$ & $87.39 * *$ & 20.67 ** \\
\hline
\end{tabular}

** İşaretli F değerleri \% I ihtimal sınırlarında çok önemli, * işaretli F değerleri \%5 ihtimal sınırlarında önemli, öd ise önemsizdir. 
Çizelge 2. Devekıran çalısının taç içi ve taç dışı farklı derinliklerinde alınan toprakların pH, EC ve Kireç’teki değişim

\begin{tabular}{|c|c|c|c|c|c|c|c|c|c|}
\hline \multirow[b]{2}{*}{ Derinlik } & \multicolumn{3}{|c|}{$\mathrm{pH}(\mathrm{I}: 2.5-\mathrm{I})$} & \multicolumn{3}{|c|}{ EC (dS m-I) } & \multicolumn{3}{|c|}{ Kireç (\%) } \\
\hline & Taç Dıșt & Taç Içi & Ort. & Taç Dışı & Taç Içi & Ort. & Taç Dıșı & Taç Içi & Ort. \\
\hline $0-20$ & $7.83 \mathrm{~b}$ & $7.99 \mathrm{~b}$ & 7.91 & 1.53 & 2.28 & 1.91 & 10.1 & 9.23 & 9.67 \\
\hline $20-40$ & $8.31 \mathrm{a}$ & $7.44 c$ & 7.88 & 1.29 & 1.66 & 1.47 & 7.32 & 8.97 & 8.15 \\
\hline $40-60$ & $8.00 \mathrm{~b}$ & $8.04 \mathrm{ab}$ & 8.02 & 1.56 & 1.58 & 1.57 & 8.17 & 10 & 9.09 \\
\hline Ort. & $8.05 \mathrm{a}$ & $7.82 \mathrm{~b}$ & & 1.46 & 1.84 & & 8.53 & 9.4 & \\
\hline
\end{tabular}

Çizelge 3. Devekıran çalısının taç içi ve taç dışı farklı derinliklerinde alınan toprakların organik madde, azot ve fosfor'daki değişim

\begin{tabular}{|c|c|c|c|c|c|c|c|c|c|}
\hline \multirow[b]{2}{*}{ Derinlik } & \multicolumn{3}{|c|}{ Organik Madde (\%) } & \multicolumn{3}{|c|}{ Azot (\%) } & \multicolumn{3}{|c|}{ Fosfor (ppm) } \\
\hline & Taç Dıșı & Taç İçi & Ort. & Taç Dıșı & Taç Içi & Ort. & Taç Dıșı & Taç Içi & Ort. \\
\hline $0-20$ & 0.18 & 0.19 & 0.19 & 0.009 & 0.009 & 0.009 & 32.74 & 27.14 & 29.94 b \\
\hline $20-40$ & 0.16 & 0.16 & 0.16 & 0.008 & 0.008 & 0.008 & 26.04 & 32.75 & $29.41 \mathrm{~b}$ \\
\hline $40-60$ & 0.19 & 0.2 & 0.2 & 0.009 & 0.01 & 0.01 & 44.02 & 33.6 & $38.8 I$ a \\
\hline Ort. & 0.17 & 0.18 & & 0.009 & 0.009 & & 34.28 & 31.16 & \\
\hline
\end{tabular}

Çizelge 4. Devekıran çalısının taç içi ve taç dışı farklı derinliklerinde alınan toprakların sodyum, kalsiyum ve potasyum'daki değişim

\begin{tabular}{|c|c|c|c|c|c|c|c|c|c|}
\hline \multirow[b]{2}{*}{ Derinlik } & \multicolumn{3}{|c|}{ Sodyum (\%) } & \multicolumn{3}{|c|}{ Kalsiyum (\%) } & \multicolumn{3}{|c|}{ Potasyum (\%) } \\
\hline & Taç Dıșı & Taç İci & Ort. & Taç Dıșı & Taç İçi & Ort. & Taç Dıșı & Taç İçi & Ort. \\
\hline $0-20$ & 0.33 & 0.32 & $0.33 \mathrm{~b}$ & $3.49 \mathrm{c}$ & $3.50 \mathrm{~b}$ & $3.49 \mathrm{~b}$ & $0.21 \mathrm{~d}$ & $0.46 \mathrm{~b}$ & $0.34 \mathrm{~b}$ \\
\hline $20-40$ & 0.29 & 0.41 & $0.35 \mathrm{~b}$ & $3.67 \mathrm{c}$ & $6.39 \mathrm{a}$ & $5.03 \mathrm{a}$ & $0.19 \mathrm{~d}$ & $0.95 \mathrm{a}$ & $0.57 \mathrm{a}$ \\
\hline $40-60$ & 0.54 & 0.41 & $0.48 \mathrm{a}$ & $3.98 c$ & $5.10 \mathrm{~b}$ & $4.54 \mathrm{a}$ & $0.33 c$ & $0.16 d$ & $0.24 \mathrm{c}$ \\
\hline Ort. & 0.39 & 0.38 & & $3.71 \mathrm{~b}$ & $4.99 \mathrm{a}$ & & 0.24 b & $0.52 \mathrm{a}$ & \\
\hline
\end{tabular}

Çizelge 5. Devekıran çalısının taç içi ve taç dışı farklı derinliklerinde alınan toprakların Magnezyum'daki değişim

\begin{tabular}{lccc}
\hline & \multicolumn{3}{c}{ Magnezyum (\%) } \\
\cline { 2 - 4 } Derinlik & Taç Dıșı & Taç Içi & Ort. \\
\hline $\mathbf{0 - 2 0}$ & $0.39 \mathrm{~cd}$ & $0.54 \mathrm{bc}$ & $\mathbf{0 . 4 6}$ \\
$\mathbf{2 0 - 4 0}$ & $0.31 \mathrm{~d}$ & $0.93 \mathrm{a}$ & $\mathbf{0 . 6 2}$ \\
$\mathbf{4 0 - 6 0}$ & $0.65 \mathrm{~b}$ & $0.44 \mathrm{~cd}$ & $\mathbf{0 . 5 4}$ \\
Ort. & $\mathbf{0 . 4 5}$ b & $\mathbf{0 . 6 3 ~ a ~}$ & \\
\hline
\end{tabular}

daha yüksek çıkmıştır. Oysa bitkinin taç içi kısmından alınan örneklerin kalsiyum (\%4.99), potasyum (\%0.52) ve magnezyum (\%0.63) içerikleri taç dışı kısmından alınan değerlere göre daha yüksek çıkmıştır.

Derinlik açısından baktığımızda en yüksek kalsiyum (\%5.03) ve potasyum (\%0.57) 20-40 cm derinlikten elde edilirken, fosfor (38.8I ppm) ve sodyum (\%0.48) miktarları 40-60 derinlikten tespit edilmiştir.

Bitkisel ve hayvansal atıkların mikroorganizmalar tarafından parçalanması sonucu oluşan organik bileşikler toprağın asitliğini artması devekıran bitkisinin kanopisindeki (taç içi) toprakların $\mathrm{pH}$ değerini düşürdüğü tahmin edilmektedir. Ayrıca, organik maddelerin parçalanması ve mineralize olması sonucu organik maddeyi oluşturan potasyum, kalsiyum ve magnezyum gibi elementler toprağa geçmekte ve toprak, bitki besin maddeleri yönünden zenginleşmektedir (Gençtan, 20I2). Araştırmamızda alınan sonuçlar bunu destekler niteliktedir.

Noureen ve ark., (2008), Pakistan'nın Cholistan Çölü'nde yürüttükleri bir çalışmada, Ebu Cehil çalısının fakir Cholistan Çölü topraklarını besin yönünden zenginleştirdiğini ve toprakların fertilitesinde önemli bir rol oynadığını ve toprağın EC, Azot, Organik Madde, Potasyum, Kalsiyum, Magnezyum, Sülfür, Fosfor ve Kireç içeriklerinin taç dışı alandaki topraklara göre, kanopi altındaki topraklarda önemli bir şekilde yüksek bulunduğunu, toprağın $\mathrm{pH}$ değerleri ise kanopi içerisinde daha düşük olarak tespit etmişlerdir. Yapılan bu çalışma elde edilen verilerimizi destekler niteliktedir.

Oktay (20/4), Iğdır ili Aralık ilçesinde doğal olarak yetişen Ebu Cehil çalısı üzerinde yaptıkları araştırmada taç içinde kalan toprakların EC, azot, organik madde, fosfor ve kireç miktarını önemli bir şekilde artırdığını, ancak $\mathrm{pH}$ değerlerini düşürdüğünü bulmuşlardır. Bu sonuçlara göre Ebu Cehil çalısının oluşturduğu kanopinin rüzgar erozyon sahasında kalan toprakların fertilitesini (verimliliğini) önemli oranda iyileştirdiği belirtmişlerdir. Araştırmamızda Devekıran çalısında taç içindeki $\mathrm{pH}$ değerindeki azalma Ebu Cehil çalısı üzerine yapılan araştırmayla benzerlik göstermiştir. Diğer taraftan Ebu Cehil çalısı üzerine yapılan araştırmayla kıyaslandığında Devekıran çalısı toprağın organik madde, EC ve kireç içeriklerini taç içinde bir miktar artırmasına rağmen, veriler üzerinde yapılan istatistiksel analizlerde bu farklılı̆̆n önemli olmadığı görülmüştür.

Taç içi/dışı x derinlik interaksiyonunda toprağın $\mathrm{pH}, \mathrm{Ca}, \mathrm{K}$ ve $\mathrm{Mg}$ içeriklerinde çok önemli bulunurken, diğer toprak özelliklerindeki interaksiyonlar önemsiz çıkmıştır (Çizelge I). Toprağın pH, Ca, K ve Mg içeriklerine ait taç içi/dışı x derinlik interaksiyonu verilerine Şekil I, 2, 3 ve 4'de verilmiştir.

Çizelge 2 ve Şekil I incelendiğinde en yüksek pH (8.3I) ile 20$40 \mathrm{~cm}$ derinlikte ve taç dışı topraklarda, en düşük pH (7.44) ile $20-40 \mathrm{~cm}$ derinlikte ve taç içi toprak kısımlarında olduğu görülmüştür. Devekıran bitkisinin taç içi kısımlarında en yüksek $\mathrm{pH}$ 40-60 ve 0-20 cm toprak derinliğinde elde edilirken, tam tersi olarak taç dışında 20-40 cm toprak derinliğinde en yüksek $\mathrm{pH}$ elde edilmiştir.

Çizelge 4 ve Şekil 2 incelendiğinde en yüksek kalsiyum \%6.39 ile $20-40 \mathrm{~cm}$ derinlikte ve taç içi topraklarda elde edilmiştir. En düşük kalsiyum oranları taç dışı topraklarda ve incelenen tüm derinliklerde $(0-20,20-40$ ve $40-60 \mathrm{~cm})$ sırasıyla \%3.49, 3.67 ve 3.98 olmuş ve derinliğe bağlı olarak kalsiyum oranında bir değişiklik olmamıştır. Taç dışı kısımlarda derinlik arttıkça topraktaki Kalsiyum miktarında artış gözlenirken, taş içi topraklarda $20-40 \mathrm{~cm}$ toprak derinliğine kadar kalsiyumda artış gözlenmiş ancak 40-60 cm toprak derinliğinde bir miktar kalsiyum içeriğinde azalma gerçekleşmiştir.

Çizelge 4 ve Şekil 3 incelendiğinde en yüksek potasyum (\%0.95) ile $20-40 \mathrm{~cm}$ derinlikte ve taç içi topraklarda, en düşük potasyum $(\% 0.16)$ ile $40-60 \mathrm{~cm}$ derinlikte ve taç içi toprak kısımlarında olduğu görülmüştür. Taç dışı toprak kısımlarda 40-60 cm derinlikte daha yüksek potasyum miktarı elde edilirken, taş içi topraklarda en yüksek potasyum içeriği 20-40 cm toprak derinliğinde elde edilmiştir.

Çizelge 5 ve Şekil 4 incelendiğinde en yüksek magnezyum (\%0.93) ile 20-40 cm derinlikte ve taç içi topraklarda, en düşük magnezyum (\%0.3I) ile 20-40 cm derinlikte ve taç dışı toprak kısımlarında olduğu görülmüştür. Taç dışı topraklarda en düşük 


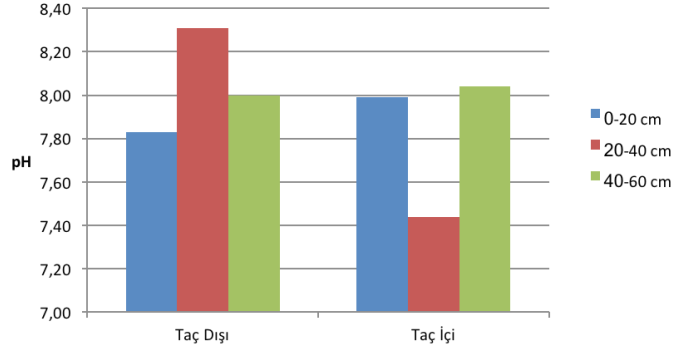

Şekil I. Devekıran çalısının taç içi/dışı ve farklı derinliklerde alınan toprakların $\mathrm{pH}$ değerleri

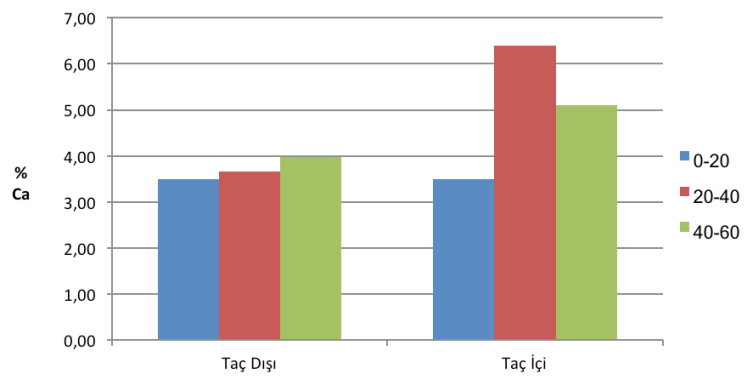

Şekil 2. Devekıran çalısının taç içi/dışı ve farklı derinliklerde alınan toprakların kalsiyum değerleri

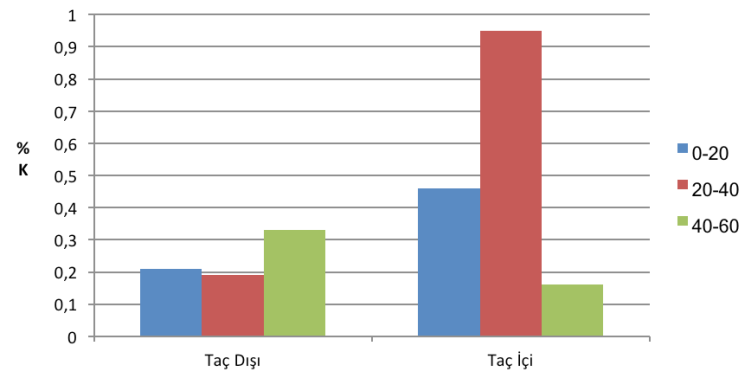

Şekil 3. Devekıran çalısının taç içi/dışı ve farklı derinliklerde alınan toprakların potasyum değerleri

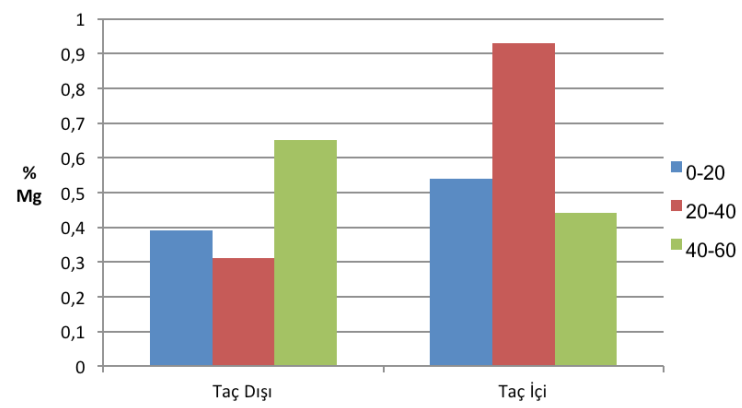

Şekil 4. Devekıran çalısının taç içi/dışı ve farklı derinliklerde alınan toprakların magnezyum değerleri
Mg içeriği 20-40 cm toprak derinliğinde elde edilirken, tam tersi olarak taç içi toprak kısımlarda aynı derinlikte en fazla miktarda Mg içeriği elde edilmiştir.

\section{SONUÇ}

Iğdır ili Aralık ilçe sınırları içerisinde yer alan rüzgar erozyon sahasında yaygın olarak yetişen Devekıran (Atraphaxis spinosa L.) çalısı ile ilgili yürütülen çalışma ile Devekıran (Atraphaxis spinosa L.) çalısının geliştiği toprakların farklı derinlik (0-20 $\mathrm{cm}, 20-40 \mathrm{~cm}$ ve $40-60 \mathrm{~cm}$ ) ve taç içi/taç dışı alınan toprak örnekleri analiz edilmiştir.

Devekıran bitkisinin kanopisi içindeki toprakların taç dışı topraklarına oranla daha asitli olduğu görülmüştür. Diğer taraftan kanopi içindeki toprakların kalsiyum, potasyum ve magnezyum içeriği yönünden taç dışı topraklara oranla daha fazla olduğu tespit edilmiştir. Diğer incelenen toprak özellikleri yönünden taç içi ve dışı arasında önemli bir farklıık görülmemiştir.

Araştırmada Devekıran çalısının yetiştiği alanlarda taç içi (kanopi) ve dışında farklı derinliklerde (0-20, 20-40 ve 40$60 \mathrm{~cm}$ ) toprak özellikleri yönünden farklılıkları incelenmiştir. Toprağın fosfor, sodyum, potasyum ve magnezyum içerikleri toprak derinliklerine bağlı olarak değişiklik göstermiş, diğer incelenen toprak özellikleri toprak derinliğine bağlı olarak herhangi bir değişikliğe uğramamıştır. Fosfor ve potasyum içeriği toprağın orta derinliğinde $(40-60 \mathrm{~cm})$ daha fazla biriktiği görülürken, potasyum ve kalsiyum içeriklerinin ise daha yüzey topraklarda $(0-20 \mathrm{~cm})$ biriktiği görülmüştür.

\section{TEŞEKKÜR}

$\mathrm{Bu}$ araştırma Iğdır Üniversitesi Bilimsel Araştırma Projeleri Koordinasyon Birimi tarafından desteklenmiş olup katkılarından dolayı teşekkür ederiz.

\section{KAYNAKLAR}

Ahmad K, Ashraf M, Khan Z, Valeem EE (2008) Evaluation of macro-mineral concentrations of forages in relation to ruminant's requirements: A case study in soone valley, Punjab, Pakistan Pak. J. Bot, 40: 295-299.

Bremner JM, Mulvaney CS (1982) Nitrogen Total. Methods of Soil Analysis Part2. Chemical and Microbiological Properties Second Edition. Agronamy. No: 9 Part 2. Edition P: 597-622.

Gençtan T (20I2) Tarımsal Ekoloji. Namık Kemal Üniv. Ders Kitabı. Genel Yayın: 6 Yayın No:3, Tekirdağ.

Ghazanfar S, Latif A, Mirza IH, Nadeem MA (20II). MacroMinerals Concentrations of Major Fodder Tree Leaves and Shrubs of District Chakwal, Pakistan. Pakistan Journal of Nutrition 10 (5): 480-484.

Koç A, Gökkuş A, Serin, Yunuz (1994) Türkiye'de ÇayırMer'araların Durumu ve Erozyon Yönünden Önemi. Atatürk Üniversitesi Ziraat Fakültesi Tarla Bitkileri Bölümü. Sayı I3. Erzurum.

Nelson RE (1982) Carbonate and Gypsum. Methods of Soil Analysis Part2. Chemical and Microbiological Properties Second Edition. Agronamy. No: 9 Part 2. Edition P: 191197.

Nelson DW, Sommers LE (1982) Organic Matter. Methods of Soil Analysis Part2. Chemical and Microbiological Properties Second Edition. Agronamy. No: 9 Part 2. Edition P: 574-579.

Noureen S, Arshad M, Mahmood K, Ashraf MY (2008) Improvement in Fertility of Nutritionally Poor Sandy Soil of Cholistan Desert, Pakistan by Calligonum Polygonoides Linn. Pak. J. Bot., 40(I): 265-274. 
Oktay G (2014) Iğdır Ekolojik Koşullarında Yetişen Ebu Cehil (Calligonum polygonoides L. ssp. Comosum (L’hér.) ) Çalısının Yıllık Besin İçeriği Değişiminin ve Bazı Özelliklerinin Belirlenmesi, Iğdır Üniversitesi Fen Bilimleri Enstitüsü, Yüksek Lisans Tezi.

Özdoğan N (1976) Rüzgar Erozyonu ve Rüzgar Erozyonu Sahalarında Alınacak Başlıca Tedbirler. Toprak Su Genel Müdürlüğü Yayınları, 306, Ankara.

Rhoades JD (1982) Soluble Salts. Methods of Soil Analysis. Part 2. Chemical and Microbiological Properties. 2nd Edition. Agronomy No: 9, 167-179, II59 p, Madison, Wisconsin USA.

Sağlam MT (1994) Toprak ve Suyun Kimyasal Analiz Yöntemleri. Trakya Üni. Tekirdağ Ziraat Fak. Yayın No; 189, Yardımcı Ders Kitabı No; 5.
Sevim Z (1999) Iğdır Aralık'ta Rüzgar Erozyonu. T.C. Başbakanlık Köy Hizmetleri Genel Müdürlüğü Köy Hizmetleri Araştırma Enstitüsü, Eruzurum.

Tan M, Temel S (20I2) Alternatif Yem Bitkileri. Atatürk Üniv. Ziraat Fak. Ders Yayınları No: 246, 195-207, Erzurum.

Temel S, Şimşek U (20I I) Iğdır Ovası Toprakların Çoraklaşma Süreci ve Çözüm Önerileri. Alınteri Zirai Bil. Der.(Alınteri J of Agr. Sci.). 2 I (B): 53-59.

Temel S, Tan M (20II) Fodder Values of Shrub Species in Maquis in Different Altitudes and Slope Aspects The Journal of Animal and Plant Sciences (The JAPS). 2 I (3), 508-5I2. 